\title{
Interactions between the Agulhas Current and the eastern margin of the Agulhas Bank
}

\author{
Marjolaine Krug ${ }^{\mathrm{a}, \mathrm{b}, \mathrm{c}, *}$, J. Tournadre ${ }^{\mathrm{d}}$, F. Dufois ${ }^{\mathrm{b}, \mathrm{e}}$
}

\begin{abstract}
a Ecosystem Earth Observation, Council for Scientific and IndustrialResearch, Cape Town, South Africa
${ }^{b}$ Oceanography Department, Mare Institute, University of Cape Town, Cape Town, South Africa

c Nansen-Tutu Center for Marine Environmental Research, James Building, University of Cape Town, South Africa

d Laboratoire d'Océanographie Spatiale, IFREMER, Plouzané, France

${ }^{e}$ CSIRO Marine and Atmospheric Research, Floreat, Australia
\end{abstract}

*: Corresponding author : Marjolaine Krug

\begin{abstract}
:
Interactions between the Agulhas Current and the ecologically important region of the Agulhas Bank are studied through the analysis of high resolution along-track altimetry, merged mapped altimetry and in situ measurements of current speed and direction undertaken from a moored Accoustic Doppler Current Profiler (ADCP). Comparisons between current observations collected from the ADCP and the satellite altimeters are made to evaluate the validity of the analysis conducted on the altimetry. Both altimetry and in situ observations show that Natal Pulses are a major driver of variability along the eastern margin of the Agulhas Bank. On average, it is estimated that the circulation along the eastern margin of the Agulhas Bank is influenced by Natal Pulses for 110 days per year. In the outer shelf region, the offshore displacement of the Agulhas Current's front associated with the passage of the Natal Pulse meander drives a strong cyclonic circulation. Closer to the shore, the impact of a Natal Pulse is felt primarily through the intrusion of the Natal Pulse's leading edge onto the shelf. While Natal Pulses are responsible for the largest temperature and current velocity anomalies recorded in the in situ dataset, most of the intra-annual variability observed along the continental slope of the Agulhas Bank and east of $20^{\circ} \mathrm{E}$, occurs over shorter time-scales and is currently not adequately observed using altimetry.
\end{abstract}

\section{Highlights}

The Agulhas Current strongly influences the circulation of the Agulhas Bank. The influence of the Agulhas Current is strongest during Natal Pulse events. Natal Pulses impact the Agulhas Bank circulation for 110 days per year on average. Natal Pulses could be instrumental in maintaining the cool ridge. Sub-sampling severely limits Altimetry in the Agulhas Bank region.

Keywords: Agulhas Current ; Agulhas Bank ; Natal pulse ; Satellite oceanography ; Altimetry 


\section{Introduction}

The Agulhas Bank, which encompasses the shelf and coastal regions south of Port Elizabeth (between $18^{\circ} \mathrm{E}-26^{\circ} \mathrm{E}$ and $34.8^{\circ} \mathrm{S}-36.9^{\circ} \mathrm{S}$ ), is one of the major nursery and spawning areas along the South African coastline (Hutchings et al., 2002). The eastern margin of the Agulhas Bank located east of $20^{\circ} \mathrm{E}$ (Hutchings, 1994) is estimated to currently support around two-thirds of the Cape Anchovy spawner population (Roy et al., 2007). The Agulhas Bank is also home to a far greater variety of fish species than the west coast upwelling ecosystem (Hutchings, 1994). Understanding the oceanography of the Agulhas Bank and the retention/advection mechanisms which regulate the transport of waters from the Agulhas Bank to the upwelling region of the west coast, is essential for the adequate management of a variety of economically and ecologically important fish species around the southern African continental shelf. A good knowledge of ocean current conditions on the Agulhas Bank is also important for a number of major economic activities such as fishing, oil and mineral exploration or ship routing.

On its eastern margin, the oceanography of the Agulhas Bank is directly 
influenced by the Agulhas Current, which flows southward along the continental shelf break (Boyd and Shillington, 1994). The Agulhas Current impacts on the circulation and hydrography of the Agulhas Bank through a range of processes such as: variations in the Agulhas Current's strength, Agulhas Current intrusions onto the outer Agulhas Bank, Agulhas Current meanders, filaments, and water plumes. A stronger Agulhas Current will induce increased Ekman veering along the landward edge of the Agulhas Current and favour the upwelling of cold and nutrient-rich water to the surface (Lutjeharms, 2006). Frontal meanders in the Agulhas Current contribute to water exchange both along and across the Agulhas Bank's shelf (Boyd and Shillington, 1994). Frontal meanders are associated with warm water plumes at their leading edge which disperse over parts of the Agulhas Bank to bring warm water to the upper layers of the water column (Lutjeharms, 2006). Frontal meanders are also associated with cyclonic cold core eddies. These cyclonic eddies may support productivity and larval recruitment through upwelling in their core and retention of drift materials (Hutchings, 1994). One type of meander in the Agulhas Current which has received considerable attention in the past is the Natal Pulse. Natal Pulses are large meanders of the Agulhas Current which originate near the Natal Bight $\left(29^{\circ} \mathrm{S}\right)$ (Lutjeharms, 2006). Natal Pulses occur at irregular intervals with on average between 1 and 2 Natal Pulses per year progressing to the southern Agulhas Current region (Goschen and Schumann, 1990; Rouault and Penven, 2011). Lagrangian float observations have revealed that Natal Pulses can extend to the full depth of the Agulhas Current (Lutjeharms et al., 2001). In-situ observations in the northern Agulhas region (at $30^{\circ} \mathrm{S}$ ) have shown that Natal 
Pulses can drive upwelling near the continental slope to the order of $50 \mathrm{~m}$ to $100 \mathrm{~m}$ per day (Bryden et al., 2005).

The circulation of the Agulhas Bank has been studied predominantly using in-situ observations (Swart and Largier, 1987; Boyd and Shillington, 1994) or numerical simulations (Penven et al., 2001; Chang, 2009; Blanke et al., 2009). Past observational studies of the Agulhas Bank oceanography have lacked the long term temporal component of the variability and have often only provided a synoptic picture of the state of the ecosystem at a given time (Swart and Largier, 1987; Boyd and Shillington, 1994; Goschen and Schumann, 1990). Descriptions of ocean currents on the Agulhas Bank from measurements date back to the late 1980s/early 1990s and there is a definite need for a more contemporary portrayal of the Agulhas Bank circulation. There have also been few in-situ observations of Natal Pulses in the southern Agulhas Current region and their impact on the eastern margin of the Agulhas Bank remains largely unknown.

The research presented in this paper aims to better characterise interactions between the Agulhas Current and the coastal and shelf regions located on the eastern margin of the Agulhas Bank. Particular focus is placed on the influence of Natal Pulses on the surrounding flow. Previous work (Rouault and Penven, 2011; Krug and Tournadre, 2012) have shown that absolute geostrophic currents derived from altimetry can be used to successfully monitor large variations in the path of the Agulhas Current in the southern Agulhas region. In this study, we use over 20 years of observations from satellite altimeters to identify Natal Pulses and assess their impact on the circulation of the Agulhas Bank, east of Cape Agulhas $\left(20^{\circ} \mathrm{E}\right)$. A 1-year record of in-situ 
Acoustic Doppler Current Profiler (ADCP) current measurements provides added insight on the influence of the Agulhas Current on the vertical structure of the water column for shelf waters on the eastern margin of the Agulhas Bank. Comparisons between current observations collected from the moored ADCP and from satellite altimeters are made to evaluate the validity of the analysis conducted on the altimetry. The data and methodology used for this research are described in Section 2. Results are presented in Section 3. A discussion of the main results is provided in Section 4 followed by the conclusions in Section 5.

\section{Data and Method}

\subsection{Merged altimetry}

Absolute geostrophic velocities derived from the Ssalto/Duacs Gridded Absolute Dynamic Topography are used to identify occurrences of Natal Pulses in the southern Agulhas Current. The mapped geostrophic velocities were downloaded from the AVISO website (up-to date DT-MADT product) and are referenced throughout this manuscript as the AVISO mapped geostrophic velocities. The up-to-date AVISO DT-MADT product combines data from all available altimeters, including ERS 1/2, Geosat, GFO and Cryosat, Jason 1/2 and Envisat. It is provided at weekly intervals and on a rectilinear grid with a $1 / 3^{\circ}$ spatial resolution. Krug and Tournadre (2012) have shown that the AVISO mapped product is well suited to monitor large variations in the path of the Agulhas Current south of Port Elizabeth $\left(34^{\circ} \mathrm{S}\right)$. In this paper, the same method as that described in Krug and Tournadre (2012) is used. The AVISO mapped geostrophic velocities are linearly in- 
terpolated onto selected altimeter tracks at a $0.1^{\circ}$ resolution. The central position of the Agulhas Current core is then defined as the local maximum in current speed in the direction of the mean Agulhas Current flow (southwest). The method of Krug and Tournadre (2012) has the advantage of providing a simple and objective method for estimating the Agulhas Current's position which compares very well with other more complex methods applied on along-track altimetry or SST imagery datasets. To track Natal Pulses, we monitor offshore excursions in the Agulhas Current along 2 transects, corresponding to the Topex/Jason altimeter's Tracks \#020 and \#198 (Figure 1). Only those excursions in the path of the Agulhas Current core exceeding 1 standard deviation from the mean at Track \#020 are considered to be associated with Natal Pulse events. Instances of Natal Pulses along Track \#020 are then followed along Track \#198. Over the period of analysis (1993-2012), 3 very large deviations (exceeding 3 standard deviations from the mean) in the Agulhas Current's path were observed. Two of these large excursions, occurring in December/January 2001 and August 2008 were associated with cases of Early Retroflection (Rouault et al., 2010; Rouault and Penven, 2011). In our analysis on the impact of Natal Pulses on the Agulhas Bank, the 3 largest deviations along Track \#020 are considered not to be cases of Natal Pulses and are therefore discarded. A zero-crossing method applied to the Agulhas Current's position anomaly (equal here to the deviation from the mean) is used to determine the duration of Natal Pulse events. The duration of each Natal Pulse is defined as the time interval separating the two zero-crossing points which surround the detected Natal Pulse. Composites of the typical circulation associated with Natal Pulse events are 
derived. Each Natal Pulse composite is defined as the time-averaged absolute geostrophic velocity fields over the duration of the Natal Pulse. No-Pulse conditions on the Agulhas Bank correspond to situations when neither a Natal Pulse nor a very large offshore excursion in the Agulhas Current's path (> 3 standard deviations) can be detected along Track \#020 or Track \#198. Comparisons between the homogeneous AVISO Reference product and the non-homogenous AVISO Updated product (not shown) lead to very similar outputs.

\subsection{Along-Track altimetry}

To assess the influence of the Agulhas Current on the circulation of the Agulhas Bank, we also use the high resolution (20 Hz for Jason-1 and -2, $10 \mathrm{~Hz}$ for Topex) along-track altimetry data collected along Tracks \#020 and \#198 (Figure 1) which is provided in the Geophysical Data Records (GDR). The cross-track velocities are derived using a method similar to that described in Krug and Tournadre (2012). The high resolution SSH data are corrected for tides, sea state bias, ionosphere, inverse barometer, dry and wet troposhere using interpolated $1 \mathrm{~Hz}$ GDR's corrections. The SSH observations obtained during the Topex and Jason-1 and -2 missions are thus collated to create a 20-year record. They are then re-sampled to a consistent set of latitude and longitude values. The SSH from Topex and Jason-2 are calibrated versus Jason-1 using the following procedure. The tandem missions between Topex and Jason-1 and Jason-1 and Jason-2, i.e. the calibration/validation periods ( $\sim 6$ months) during which the satellites fly on the same orbit with a time separation of the order of one minute, are used to compute a mean SSH difference. This difference is then compared to the 
difference between the mean SSHs computed over the whole archive of each satellite to insure that no large trend in the mean SSH exists, which is not the case for Tracks \#20 and \#198. The mean tandem SSH differences are then used to calibrate the Topex and Jason-2 SSH versus Jason-1. The Mean Sea Surface $M S S$ is then computed using the calibrated 20-year long record. The Absolute Dynamic Topography (ADT) is then estimated as $A D T=S S H-$ $M S S+M D T$ where $M D T$ is the along-track Mean Dynamic Topography of Rio et al. (2011). The absolute geostrophic cross-track velocities $V_{g}$ are defined as $V_{g}=\frac{g}{f} \frac{\partial A D T}{\partial d s}$, where $g=9.8 \mathrm{~ms}^{-2}$ is the standard gravity, $f$ is the Coriolis parameter and $\frac{\partial A D T}{\partial d s}$ is the ADT gradient along the altimeter's track. The ADT are filtered using a Lee filter (Lee, 1981) of $2.8 \mathrm{~km}$ length $(1020 \mathrm{~Hz}$ samples) and the cross-track velocities are calculated from the filtered ADT and are themselves subsequently filtered with a Lee filter of $5.6 \mathrm{~km}$ length (20 samples). The nominal resolution of the velocities is $0.28 \mathrm{~km}$ while the length scale are of the order of $5.6 \mathrm{~km}$.

\subsection{In-situ observations}

Approximately 1 year of current speeds and directions collected from a moored ADCP are used in this study. An upward looking $150 \mathrm{kHz}$ Teledyne RD Instruments Quartermasters ADCP was moored at $22^{\circ} 43^{\prime} \mathrm{E}-35^{\circ} 10^{\prime} \mathrm{S}$ in water depths of $250 \mathrm{~m}$, on the continental slope of the Agulhas Bank (Figure 1). All ADCP data were collected and processed by the coastal systems group of the Council for Scientific and Industrial Research (CSIR) on behalf of PetroSA. The ADCP was set to measure at 30-minute intervals, with data collected every $10 \mathrm{~m}$ throughout the water column, from depths of $230 \mathrm{~m}$ to $30 \mathrm{~m}$ below the sea surface. The processing of the data involved flag- 
ging data points associated with low correlation beam counts, checking for spikes or invariant current speed values as well as removing spurious data collected near the surface and during the deployment and recovery times. The ADCP record extends from 5 April 2009 to 17 April 2010 and encompasses 2 Natal Pulse events. The proximity of the ADCP deployment site to the TOPEX/Jason Track \#198 (14.2 km) allows us to ground truth the altimetry datasets. To compare the ADCP and altimetry observations, all ADCP data are low-passed filtered with a cut-off of 36-Hour in order to remove tidal and inertial oscillations. Preliminary analyses (not shown) revealed that most of the energy in the ADCP current velocity spectra could be attributed to lower frequency processes associated with periods of 7 days or greater. The contribution of tidal and inertial oscillations to the ADCP current velocity energy spectra was small. The small contribution of the tides to ocean current oscillations at the ADCP mooring site was also highlighted in a technical report compiled by the CSIR (Grundlingh et al., 2010). All ADCP observations presented in this paper are from the 36-Hour low-passed filtered ADCP dataset.

Water temperatures collected from the ADCP's temperature sensor at a depth of $230 \mathrm{~m}$ are used. The near sea-bed water temperature fluctuations are compared to satellite based Sea Surface Temperature (SST) measurements in order to relate dynamical forcing to water temperature variations at the ADCP mooring site. SST values are extracted within a $0.25^{\circ}$ square around the ADCP mooring site from the hourly SEVIRI SST product processed by the French ERS Processing and Archiving Facility (CERSAT) and available on a $0.05^{\circ}$ grid (http://www.osi-saf.org). Both the satellite and ADCP 
temperature records are then low-passed filtered with a 36-Hour cut-off and sub-sampled to daily averages. No distinct annual cycle was observed in the near sea-bed water temperature record and the water temperature anomalies near the seabed were defined as temperature variations from the mean. A daily climatology (not shown) was derived from the SST dataset using 30-day running averages centred around each day of the year. The SST anomalies were then calculated by removing the daily climatology from the SST record.

\section{Results}

\subsection{Influence of the Agulhas Current on surrounding waters from altimetry}

In order to better understand interactions between the Agulhas Current and the circulation of the Agulhas Bank, the effect of deviations in the Agulhas Current's path on the surrounding current velocity field were assessed using over 20 years of altimetry observations (Figure 2). The position of the Agulhas Current core was determined using the AVISO mapped altimetry product as described in Section 2. Properties of Natal Pulses such as their periodicity, offshore extent and duration were all derived using the AVISO mapped altimetry product.

Shades of blue in Figure 2a and Figure 2b show the strong south-westerly flow associated with the dynamical core of the Agulhas Current along Tracks \#020 and \#198, respectively. Orange and red colors further offshore are indicative of the north-easterly flowing Agulhas Return Current. Cross-track geostrophic current velocities within the Agulhas Current core are often in

excess of $2 \mathrm{~ms}^{-1}$ along both Tracks \#020 and \#198. The Agulhas Current as portrayed in the high resolution along-track altimetry is generally narrower 
and stronger at Track \#020 than at Track \#198. The time-averaged crosstrack velocities over the full length of the along-track altimetry record $(\sim 20$ years) reduce from $1.25 \mathrm{~ms}^{-1}$ at Track \#020 to $1 \mathrm{~ms}^{-1}$ at Track \#198. Using the $0.1 \mathrm{~ms}^{-1}$ isotach of cross-track geostrophic velocity as a measure of the overall current's width, we find that the Agulhas Current's width increases from about $190 \mathrm{~km}$ at Track \#020 to $220 \mathrm{~km}$ at Track \#198. Results based on both the mapped and high resolution along-track altimetry datasets show that the Agulhas Current follows the continental shelf, with its centre moving progressively away from the coast from $114 \mathrm{~km}$ along Track \#020 (Figure 2a) to $207 \mathrm{~km}$ along Track \#198 (Figure 2b). Analysis conducted on the AVISO mapped altimetry show that the Agulhas Current tends to meander more along the southernmost track with standard deviations of its path's position increasing from $33 \mathrm{~km}$ at Tracks \#020 to $40 \mathrm{~km}$ at Track \#198. Using the AVISO mapped altimetry product, we estimate that offshore excursions in the path of the Agulhas Current along Track \#020 exceeding 1 standard deviation from the mean occur on average 1.7 times per year, in agreement with Rouault and Penven (2011). Between 14 October 1992 and 18 April 2012, 30 instances of Natal Pulses (as defined in Section 2) are detected along Track \#020. Natal Pulses occur at irregular times throughout the 20-year length of the altimetry record with at times, no Natal Pulse for two consecutive years (between 1995 and 1997) and at other times, as many as 4 Natal Pulses per year being detected, such as during the year of 2010. Analysis conducted on the AVISO mapped altimetry product show that on average, Natal Pulses persist for about 1.5 months (65 days) along both Tracks \#020 and \#198, but the duration of Natal Pulses is variable, ranging 
from 3 weeks to 2.5 months. At Track \#020, deviations in the path of the Agulhas Current from the mean current position caused by the passage of a Natal Pulse vary from about $35 \mathrm{~km}$ to $115 \mathrm{~km}$, with most Natal Pulses causing offshore deviations in the mean current path of 50 to $60 \mathrm{~km}$. Further south, along Track \#198, Natal Pulses are on average slightly bigger in size with a mean offshore deviation of about $85 \mathrm{~km}$. The size of Natal Pulses along Track \#198 display more pulse to pulse variability, with the standard deviation in the size of Natal Pulses increasing from $25 \mathrm{~km}$ to $45 \mathrm{~km}$ from Track \#020 to Track \#198. Natal Pulses take on average about 22 days to progress from Track \#020 to Track \#198, which amounts to a southward propagation speed of about $10 \mathrm{~km} /$ day, in agreement with Lutjeharms et al. (2003b). The AVISO mapped geostrophic velocities are provided at weekly time-intervals. An uncertainty of 7 days in the time of the Natal Pulse's arrival would result in an error in the estimation of the southward propagation speed of about $2 \mathrm{~km} /$ day.

The high resolution along-track altimetry shows that each Natal Pulse identified in Figure 2 induces strong flow anomalies around the location where the Agulhas Current usually resides, with current reversals from a predominant south-westerly flow to a strong north-easterly flow. Each Natal Pulses peak is coincident with period of strong north-easterly current with order of magnitude of about $1 \mathrm{~ms}^{-1}$ (Figure 2). The arrival of Natal Pulses is often preceded by an onshore intrusion of the Agulhas Current and a strengthening in the south-westerly component of the flow (Figure 2). The spatial extent of the velocity perturbations typically associated with Natal Pulses is revealed in composites maps generated from the AVISO mapped 
altimetry dataset using the 30 Natal Pulses identified in Figure 2. The current velocity anomalies associated with Natal Pulses represent differences between the composite-averaged velocity fields and the climatological mean during No-Pulse conditions (as defined in Section 2). Figure 3 shows AVISO maps of geostrophic current anomalies computed at varying time delays before and after the passage of Natal Pulses across Track \#020. Negative time delays show typical geostrophic current anomalies experienced before Natal Pulses can be detected along Track \#020. Positive time delay show typical geostrophic current anomalies experienced after Natal Pulses are detected along Track \#020. A time delay of 0 day (Figure 3d) shows the average current anomaly field when a Natal Pulse is present along Track \#020. Figure $3 \mathrm{f}$ shows current velocity anomalies experienced 20 days after the passage of Natal Pulses along Track \#020, and represents current anomalies typical of when a Natal Pulse is encountered at Track \#198. In the AVISO composite maps, Natal Pulse conditions are associated with extensive cyclonic anomalies in the circulation. These cyclonic anomalies suggest weaker than average currents at the usual location of the Agulhas Current (in shades of green and blue) and a stronger than normal south-westerly flow where the offshore edge of the Agulhas Current usually resides (in shades of orange and red). Figure 3 shows that Natal Pulses start to impact on the circulation of the Agulhas Bank from about 30 days before they are encountered along Track \#020 to about 40 days after their passage past the location of Track \#020. The time difference between the first detection of Natal Pulses at Track \#020 to their last detection at Track \#198 similarly shows that Natal Pulses reside on the eastern margin of the Agulhas Bank for periods 
of 65 days, on average. As Natal Pulses approach Track \#020 (35 S), the cyclonic anomaly in the current velocity field increases in both size and magnitude. The strongest anomaly in the circulation is observed about 10 days after the peak of the Natal Pulse at Track \#20, when Natal Pulses are midway between Tracks \#020 and \#198 (Figure 3e). At this stage, the AVISO maximum velocities anomalies typically reach $0.5 \mathrm{~ms}^{-1}$ to $0.7 \mathrm{~ms}^{-1}$ and the region of anomalous flow extends $350 \mathrm{~km}$ in length and $180 \mathrm{~km}$ in width. Throughout a Natal Pulse's southward progression, the cyclonic anomaly cell is roughly aligned with the $3000 \mathrm{~m}$ isobath, with its inshore edge typically bounded by the $200 \mathrm{~m}$ isobath. When Natal Pulses are detected along Track \#020 (Figure 3d), most of the associated cyclonic anomaly can be encountered west of Track \#020. This indicates that when Natal Pulses are detected at Track \#020, over the duration of the Natal Pulse the offshore meander is encountered for a greater portion of the time to the west of Track \#020. In contrast, by the time a Natal Pulse reaches Track \#198 (Figure 3f), the cell of anomalous flow is encountered east of Track \#198 throughout the greater part of the Natal Pulse's duration. Figure 3c, d, e, f and g, show that the propagation speed of Natal Pulses decreases southward of Port Elizabeth and that Natal Pulses tend to get trapped at the Agulhas Bank's Bight (at about $23^{\circ} \mathrm{E}$ ). Results from the composite analysis conducted on the AVISO mapped product and plotted in Figure 3 suggest that Natal Pulses do not generally cause large anomalies in the current velocity field west of $22^{\circ} \mathrm{E}$ and inshore of the $200 \mathrm{~m}$ depth contour.

Natal Pulse composites computed using the high resolution along-track altimetry dataset (Figure $4 \mathrm{a}$ and $4 \mathrm{~b}$ ) similarly show that the largest current 
anomalies associated with Natal Pulse events are encountered in the regions where the Agulhas Current usually resides. The offshore displacement of the Agulhas Current during a Natal Pulse event causes weaker than average currents at the usual location of the Agulhas Current. Where the offshore edge of the Agulhas Current usually resides, a stronger than normal southwesterly flow occurs. When averaged over the duration of a Natal Pulse event, the flow retains a predominantly south-westerly direction and the region of south-westerly flow typically associated with the Agulhas Current becomes weaker and wider (Figure $4 \mathrm{a}$ and $4 \mathrm{~b}$ ). Composites of the initial, peak, and final stages of Natal Pulses were computed from the high resolution alongtrack altimetry to provide some information on the evolution of the velocity field throughout Natal Pulse events. The initial stage of a Natal Pulse (green line in Figure 4) is associated with the intrusion of the Agulhas Current water onto the shelf break. Along Track \#020, these Agulhas Current intrusions occur as close as $30 \mathrm{~km}$ from the coastline while at Track \#198, the Agulhas Current intrusions do not extend beyond $100 \mathrm{~km}$ from the shore. As the offshore extent of the Natal Pulse along the altimeters' tracks reaches its maximum, a strong cyclonic circulation is set-up along the continental shelf break. When Natal Pulses progress across Tracks \#020 and \#198 and their offshore extent is at a maximum (blue line in Figure 4), a north-easterly flow is encountered along the continental slope, landward of the Agulhas Current's front. At Track \#020, this return north-easterly current is typically associated with a peak amplitude of $0.5 \mathrm{~ms}^{-1}$ and a width of about $60 \mathrm{~km}$. At Track \#198, the north-easterly return flow is slighter weaker and narrower with peak velocities reduced to about $0.35 \mathrm{~ms}^{-1}$ and a width of about $50 \mathrm{~km}$. 
The composite analysis on the high resolution along-track altimetry dataset shows that the Agulhas Current tends to broaden as it meanders. When the lateral extent of Natal Pulse meanders across the altimeters track reach their maximum (blue line in Figure 4), the south-westerly flow associated with the Agulhas Current becomes wider with the distance between the $0.5 \mathrm{~ms}^{-1}$ isotachs increasing by $40 \%$ to $45 \%$. The broadening of the meandering Agulhas Current observed in the along-track altimetry record is in agreement with that reported by Leber and Beal (2014) during their survey of the April 2010 Natal Pulse along the $28^{\circ} \mathrm{E}$ longitude (north of Port Elizabeth).

In the high resolution along-track altimetry dataset, the magnitude of the cross-track velocity anomaly associated with Natal Pulses far exceeds that observed using the AVISO mapped dataset. Composites computed from the high resolution along-track altimetry at Track \#020 (Figure 4) show that the cross-track velocity anomaly induced by the offshore displacement of the Agulhas Current front typically reaches $1 \mathrm{~ms}^{-1}$ instead of the $0.5 \mathrm{~ms}^{-1}$ to $0.7 \mathrm{~ms}^{-1}$ velocity anomalies estimated from the AVISO mapped dataset. In the AVISO mapped product, spatial and temporal smoothing procedures are required to produce merged maps of absolute geostrophic currents. Tournadre and Rouault (2012) noted that gridding and temporal averaging in the Agulhas Current lead to an underestimation of the velocity and a widening of the current. Hovmöller diagrams derived from the AVISO mapped product and similar to those presented in Figure 2 (not shown), show that the AVISO mapped product is unable to adequately capture periods of northeasterly current reversals during Natal Pulse events. The lack of temporal interpolation in the along-track altimetry dataset allows us to better observe 
the strong north-easterly flow reversals which often occur during Natal Pulse events. The along-track altimetry dataset shows that when the lateral extent of Natal Pulses across the altimeters track is at its maximum, velocity differences between the southward flowing Agulhas Current and the opposing north-easterly flow closer to the shore typically reach $2 \mathrm{~ms}^{-1}$ along Track \#020 and $1.2 \mathrm{~ms}^{-1}$ along Track \#198.

Both altimetry dataset however indicate that the magnitude of the current velocity anomaly associated with the passage of Natal Pulses decreases strongly southward. In the along-track dataset, the maximum cross-track velocity anomaly throughout the duration of a Natal Pulse event reduces from $1 \mathrm{~ms}^{-1}$ at Track \#020 to $0.6 \mathrm{~ms}^{-1}$ at Track \#198 (Figure 4c and 4d). Analysis on the along-track altimetry suggests that when Natal Pulses reach their maximum offshore extent, a secondary cell of flow divergence occurs between the region of north-easterly flow and the near-shore waters, with currents near the coastline flowing towards the south-west. This secondary cell of diverging flow is located on the Agulhas Bank about $50 \mathrm{~km}$ and $150 \mathrm{~km}$ from the coast along Tracks \#020 and \#198, respectively. This near-shore region of south-westerly flow observed when Natal Pulses reach their maximum size is on average weaker and narrower along Track \#020, with a width of about $30 \mathrm{~km}$ and velocities of about $0.1 \mathrm{~ms}^{-1}$. Along Track \#198, the tongue of south-westward flow observed on the Agulhas Bank extends over a $60 \mathrm{~km}$ width and is associated with current speeds of about $0.25 \mathrm{~ms}^{-1}$.

\subsection{In-situ observations}

In-situ measurements gathered on the ADCP mooring line provided additional information on the interactions between the Agulhas Current and 
the shelf waters of the Agulhas Bank. The ADCP was located on the continental shelf of the Agulhas Bank bight, about $114 \mathrm{~km}$ from the shore and approximately $50 \mathrm{~km}$ from the landward edge of the Agulhas Current.

Water temperature measured near the seabed varied between $7^{\circ} \mathrm{C}$ and $12^{\circ} \mathrm{C}$, with a mean of $9^{\circ} \mathrm{C}$. The range of water temperature at the ADCP site is suggestive of the presence of South Indian Ocean Central water (Lutjeharms, 2006). The presence of South Indian Ocean Central Water below depths of $100 \mathrm{~m}$ on the eastern margin of the Agulhas Bank has been attributed to continuous shelf-edge upwelling by the Agulhas Current (Chapman and Largier, 1989). No distinct annual cycle was observed in the near sea-bed water temperature record. SST extracted from the SEVIRI dataset at the mooring site averaged to $20.5^{\circ} \mathrm{C}$ over the period of ADCP data collection. The SST at the mooring site displayed a distinct annual cycle. SST variations in the climatology (not shown) showed summer to winter decreases of about $4^{\circ} \mathrm{C}$, with values peaking to $22.5^{\circ} \mathrm{C}$ in February and decreasing to a minimum of $18.5^{\circ} \mathrm{C}$ in August. Both the SST and near sea-bed water temperatures at the ADCP site displayed rapid fluctuations with most of the sub-annual variability occurring over time-scales of 4 to 14 days (Figure 5b and $5 \mathrm{~d})$.

ADCP observations showed a flow strongly aligned with the bathymetry, with currents aligned along an east/west axis (Figure 6). The flow at the mooring site was generally weak. Mean current speeds decreased slightly with depth from $0.3 \mathrm{~ms}^{-1}$ to $0.2 \mathrm{~ms}^{-1}$ and the predominant flow was directed towards the east/north-east. In the upper $150 \mathrm{~m}$ of the water column, the strongest currents were directed toward the west, while at deeper levels of the 
water column, the strongest currents were towards the east. The strongest currents were observed in the upper $50 \mathrm{~m}$ of the column, with maximum speeds reaching $1.7 \mathrm{~ms}^{-1}$ over the 1-year duration of the record. Standard deviations from the mean current velocities varied from $0.2 \mathrm{~ms}^{-1}$ near the surface to $0.1 \mathrm{~ms}^{-1}$ at depth. These high standard deviations from the mean current velocity profile showed the rapidly varying nature of the flow at the ADCP mooring site, with currents experiencing changes in both direction and speed over time-scales of typically less than a week (Figure 5b, c and d). The predominant easterly currents were associated with barotropic conditions at the ADCP mooring site, with homogeneous current fluctuations throughout the water column. During periods of westerly flow, current speeds showed a greater attenuation with depth.

Over the 1-year record of current observations, there were two periods during which baroclinic conditions developed at the ADCP mooring site: in April / May 2009 and December 2009 / January 2010. These two events were associated with sustained periods of westerly flow and much stronger currents experienced in the upper $150 \mathrm{~m}$ of the water column. The duration of each of these periods of anomalous westerly flow was estimated by calculating the time between zero-crossing points within the easterly current flow data. The first westerly flow event in April 2009 appeared to start prior to the initial deployment of the ADCP mooring. It was associated with westward current velocities exceeding $1 \mathrm{~ms}^{-1}$ in both the upper and intermediate levels of the water column and could be observed in the data record over a period of 22 days. The second westward current anomaly was observed over the months of December 2009 and January 2010 and was estimated to last for about 25 
days. Maximum current velocities during this second event reached $1 \mathrm{~ms}^{-1}$ in the upper layers of the water column. Figure 5 shows a distinct attenuation in the current's strength with depth during these periods of strong westerly flow. Vertical shear at the mooring location was at a maximum during the first period of westerly flow, with shear values reaching $0.02 \mathrm{~s}^{-1}$. The two periods of strong westward flow observed in the ADCP data record occurred at times when Natal Pulses were present north-east of the ADCP mooring site (Figure 5a). Geostrophic velocities derived across Track \#198 show that the period of strong westerly flow observed during April-May 2009 is due to the intrusion of the Agulhas Current onto the shelf, prior to the arrival of the Natal Pulse. A similar process seems to occur during the Natal Pulse events of December 2009-January 2010. In this instance however, the landward intrusion of the Agulhas Current is not as easily discernible in the along-track altimetry record. Daily composites maps of SST (not shown) show that the December 2009 Natal Pulse meander evolves from a solitary meander to two-meander configuration. As a result, the south-westerly flow associated with the Agulhas Current branches off, with one region of southwesterly flow located about $150 \mathrm{~km}$ from the coast and another encountered about $300 \mathrm{~km}$ from the shore (Figure 5a). The complex circulation patterns over December 2009-January 2010 make the identification of the Agulhas Current's dynamical core challenging. In their analysis of cruise data, Jackson et al. (2012) similarly noted that a Natal Pulse had caused the intrusion of warm Agulhas Current water onto the Agulhas Bank. Our observations show that warm water temperature anomalies were observed both at the surface (Figure 5b) and near the seabed (Figure 5d) when the leading edge of a 
Natal Pulse intruded onto the shelf. The warm water temperature anomalies were coincident with the peak in westerly flow and the arrival of the Natal Pulse at Track \#198 (near the ADCP). As the Natal Pulse progressed, both the magnitude of the westerly flow and the water temperature decreased. The largest water temperature anomaly observed at the mooring site could be attributed to the April 2009 Natal Pulse event. In April 2009 and over a period of 2 weeks, the intrusion of Agulhas Current water caused an increase in water temperature of about $3^{\circ} \mathrm{C}$ throughout the water column. In May 2009 and within 3 days after it had reached its peak, the water temperature at the mooring site had dropped by $5^{\circ} \mathrm{C}$. It was after this sudden water temperature drop that the lowest water temperatures were recorded both near the surface and at depth. Water temperature fluctuations associated with the December 2009 Natal Pulse were much weaker. The impact of the December 2009 Natal Pulse on the water temperature near the mooring site appeared to be more pronounced in the surface layer, causing a rise in SST of about $3^{\circ} \mathrm{C}$. The end of the period of westerly flow was followed by a slight decrease in water temperature (of the order of $1^{\circ} C$ ) which was only evident near the surface.

\subsection{Altimetry and in-situ data comparisons}

The in-situ current measurements, collected only $14 \mathrm{~km}$ away from the Topex/Jason Track\#198, were used as ground-truth to evaluate the ocean circulation depicted from the altimetry. Comparisons between the ADCP projected velocities at a depth of $30 \mathrm{~m}$ and the cross-track absolute geostrophic

current velocities derived from the high resolution along-track altimetry showed a fairly good agreement (Figure 7). Current velocities derived from the 
ADCP and the high resolution along-track altimetry differed by $-0.05 \mathrm{~ms}^{-1}$ in the mean, with a Root Mean Square Error (RMSE) equal to $0.35 \mathrm{~ms}^{-1}$. A correlation of 0.68 significant at the $99 \%$ level was found between the ADCP and the cross-track velocities derived from the high resolution altimetry. As anticipated, the 10-day sampling interval of the along-track altimetry was inadequate to capture the high frequency variability (less than 1 week) which characterised most of the flow fluctuations observed within the ADCP record, as seen in Figure 5b. In an attempt to improve the fit between the ADCP and satellite-based observations of ocean currents, we added the Ekman wind drift to the geostrophic current velocities derived from the along-track altimetry. The Ekman surface current component was estimated using wind observations from a nearby platform (Figure 1). Adding the Ekman component to the altimetry's geostrophic velocities did not markedly improve the goodness of the fit to the ADCP observations. The RMSE remained equal to $0.35 \mathrm{~ms}^{-1}$ and the mean bias was only reduced by $0.02 \mathrm{~ms}^{-1}$, while the correlation showed a marginal decrease. There appeared to be no relation between strong wind events and strong flow events at the ADCP site. Comparisons between weekly averages of ocean current speeds observed with the $\mathrm{ADCP}$ at a depth of $30 \mathrm{~m}$ and absolute geostrophic current velocities derived from the AVISO mapped altimetry showed that current velocities in the AVISO mapped product significantly under-estimated the strength of the flow at this location, with a mean bias of $-0.31 \mathrm{~ms}^{-1}$. The RMSE between the AVISO mapped altimetry and ADCP datasets was equal to $0.25 \mathrm{~ms}^{-1}$ and the correlation coefficient, with a value of 0.46 , was significantly lower than that calculated between the ADCP and the along-track altimetry. Current 
roses generated from weekly averages of ADCP observations and absolute geostrophic currents extracted from the AVISO mapped product showed that the AVISO mapped dataset was unable to capture periods of eastward flowing current at the mooring site (Figure 8). In the AVISO mapped velocity fields, the flow at the ADCP mooring site was portrayed as always being towards the west, with the strongest currents directed towards the south-west. The in-situ current observations showed that the flow at the ADCP site was predominantly to the east/north-east, with the strongest flows towards the west.

\section{Discussion}

Figure 2 and Figure 5a show that there is a remarkable agreement between the position of the Agulhas Current core derived from the AVISO mapped product and the regions of maximum south-westerly flow associated with the Agulhas Current observed in the high resolution along-track altimetry. The ability of the AVISO mapped product to correctly position the Agulhas Current core increases our confidence in the accuracy of the main statistics derived on Natal Pulses, such as the frequency of Natal Pulses, their offshore extent, their duration and their southward propagation speed. Lutjeharms et al. (1989) provided a fairly detailed description of eddies and boundary phenomena in the southern Agulhas Current using 10 years of thermal imagery. Their analysis based on visual examination of Agulhas Current's thermal front describes the tendency of the Agulhas Current to increasingly meander south of Port Elizabeth. The increasingly meandering nature of the Agulhas Current south of Port Elizabeth could be attributed 
to two processes: the first being that offshore meanders grow in size as they progress southward, the second being that additional meanders are generated south of Port Elizabeth. Previous studies have pointed to the eastern Agulhas Bank as a region of shear-edge eddy generation (Lutjeharms et al., 2003b,a). Lutjeharms and van Ballegooyen (1984) attributed the formation of these shear-edge eddies to a decrease in topographic steering at the widening Agulhas Bank, south of Port Elizabeth. Time-series of the Agulhas Current's path derived from the altimetry (Figure 2) confirm the increasingly meandering nature of the Agulhas Current south of Port Elizabeth. The analysis conducted on the AVISO mapped dataset indicate that on average, deviations in the path of the Agulhas Current caused by Natal Pulses increase by about $30 \mathrm{~km}$ from Track \#020 to Track \#198. Our analysis shows that over the 20-year long altimetry record, the number of Natal Pulses detected along Track \#020 and Track \#198 would only increase by 1 if the threshold for meander detection used along Track \#020 was applied to detect Natal Pulses along Track \#198. These results suggest that between Track \#020 and Track \#198, it is the size of the meanders rather than their frequency which increases. Meanders smaller than Natal Pulses can develop and evolve rapidly. Monitoring the growth and generation of small scale meanders with altimetry is challenging due to the large spatial gaps between altimeter's tracks and the low temporal resolution of most altimeters (typically $>10$ days). Observations at higher spatial and temporal resolutions would be required to assess whether strong cyclogenesis occurs south of Port Elizabeth.

Composite maps of the anomalous current fields derived from the altimetry products provided some useful information on the influence of Natal 
Pulses on the surrounding flow. Both the high resolution along-track and the AVISO mapped altimetry datasets showed that the offshore displacement of the Agulhas Current front during Natal Pulse events results in a cyclonic velocity anomaly, centred above the mean position of the Agulhas Current core. In the AVISO mapped altimetry, the cyclonic velocity anomaly took the shape of an ellipsoid with maximum dimensions of about $350 \mathrm{~km}$ by $180 \mathrm{~km}$. In this dataset, the cell of anomalous flow was symmetrical around its semimajor axis, with velocity anomalies reaching amplitudes of about $0.5 \mathrm{~ms}^{-1}$ on either side of the ellipse's semi-major axis. The composite analysis conducted on the high resolution along-track altimetry dataset showed that in fact, the region of cyclonic flow associated with Natal Pulses was asymmetric, with much stronger velocity anomalies on the landward edge of the Agulhas Current (Figure 4a and 4b). Composites maps of the cell of anomalous flow associated with Natal Pulses suggest that the impact of Natal Pulses on the circulation of the Agulhas Bank and east of $20^{\circ} \mathrm{E}$, is strongest about 10 days after the Natal Pulse reaches its maximum offshore extent along Track \#020, when the Natal Pulse is centered at a longitude of about 25E (Figure 3e). Our results also show that Natal Pulses slow down as they progress south of Port Elizabeth, to remain trapped for considerable period of time along the bight of the Agulhas Bank, affecting most strongly regions within the longitudes of $23^{\circ} \mathrm{E}-26^{\circ} \mathrm{E}$ (Figure 3 ). This result is consistent with early modelling studies (Lutjeharms et al., 2003a) which have shown that shear-edge eddies which develop in the southern Agulhas region tend to remain trapped in the Agulhas Bank shelf bight. Both altimetry datasets showed an significant attenuation in the magnitude of the flow anomaly associated with Natal 
Pulses from Track \#020 to Track \#198. The along-track altimetry dataset showed a $40 \%$ decay in the magnitude of the north-westward flow anomaly between Track \#020 and Track \#198. This implies that Natal Pulses loose a significant amount of energy to the surrounding flow as they progress southward along the continental slope of the Agulhas Bank. The manner in which Natal Pulses loose energy to the surrounding flow falls beyond the scope of this paper and could be investigated in future research.

The ADCP record provided some additional information on the impact of the Agulhas Current on the Agulhas Bank. The flow at the ADCP site was predominantly barotropic. Most fluctuations in current speed and direction occurred over time-scales of a few days to about 1 week and could not be related to local wind forcing. Sustained periods of easterly flow at the ADCP site appeared to be related to small-scale meanders in the Agulhas Current. Such periods of easterly flow could also be observed in the high resolution along-track altimetry around August 2009, early September 2009 and October 2009 (Figure 5). In the in-situ record, the strongest current and temperature anomalies could be attributed to the leading edge of Natal Pulses intruding onto the Agulhas Bank. Both the April and December 2009 Natal Pulses induced strong westward flow in the upper to intermediate levels of the water column as well as a significant warming. The impact of the April 2009 Natal Pulse on the circulation over the shelf of the Agulhas Bank was much stronger than that induced by the Natal Pulse of December 2009. The April 2009 and December 2009 Natal Pulses were very similar in size but the cyclonic flow anomaly associated with the April 2009 was much stronger than that observed during the December 2009 Natal Pulse event 
(Figure 5a). This results suggests that the influence of Natal Pulses on the shelf of the Agulhas Bank could be related to the magnitude of the cyclonic anomaly associated with a Natal Pulse, rather than to the Natal Pulse's offshore amplitude. It is worth noting that the north-easterly currents observed in the altimetry record over the mean position of the Agulhas Current in April 2009 were stronger than those experienced during most other Natal Pulse events (Figure 2). When the Agulhas Current intruded onto the shelf, baroclinic conditions developed at the ADCP mooring site, with upper and intermediate layers of the water column experiencing much stronger currents than waters located below depths of about $150 \mathrm{~m}$. Previous ADCP measurements (Beal and Bryden, 1999; Bryden et al., 2005) have revealed a V-shaped pattern across the Agulhas Current where the position of the current maxima moves offshore with increasing depth. Here, we attribute the vertical velocity shear experienced during Agulhas Current intrusions to the baroclinic nature of the Agulhas Current. Temperature variations caused by the intrusion of Agulhas Current water onto the shelf during Natal Pulse events were by contrast barotropic in nature. In a previous study Van der Vaart and de Ruijter (2001) similarly reported a disparity between the vertical structure of the current and water temperature fields in Natal Pulses. Periods of Agulhas Current intrusions onto the Agulhas Bank were often visible in the high resolution along-track altimetry dataset (Figure 2 and Figure 5a). Natal Pulse composites derived from the high resolution alongtrack altimetry data (Figure 4a) show that over the duration of a Natal Pulse, shelf regions on the eastern margin of the Agulhas Bank (about 50km from shore near Track \#020 and 120km from the shore along Track \#198 
in Figure 4b) experience stronger than normal south-westerly currents. The stronger than normal westward flow experienced closer to the shore during Natal Pulse events is due to 1) Agulhas Current intrusions during the initial stages of Natal Pulses and 2) the development of a westward flowing current over the Agulhas Bank when Natal Pulses reach their maximum offshore extent. Based on the high resolution along-track composite analysis, Natal Pulses have a greater impact on the mid-Agulhas Bank bight than near Algoa bay. At Track \#020, south-westward current anomalies in the along-track altimetry record encountered over the continental slope remain typically below $0.1 \mathrm{~ms}^{-1}$ and were confined within a $30 \mathrm{~km}$ band (Figure 4c). At Track \#198, the region of south-westward current anomaly extended over a width of $60 \mathrm{~km}$ on average with cross-track velocity anomalies of about $0.2 \mathrm{~ms}^{-1}$ (Figure 4d).

One of the unique feature of the central and Eastern Agulhas Bank is the cool ridge. The cool ridge has been described as a quasi-permanent subsurface tongue of cold water which extends south-westerly, roughly following the $100 \mathrm{~m}$ isobath and extending seawards off the coast (Hutchings, 1994). The cool ridge has been observed as a gentle doming of the isotherms in the vertical, in contrast to the steep tilting of the isotherm associated with shelf edge upwelling closer to the coast (Probyn et al., 1994). The cool ridge appears to play an important role in the distribution and productivity of pelagic fish but its origin and dynamics remain poorly understood (Hutchings et al., 2009). Some studies favour the hypothesis that the cool ridge is linked to coastal driven upwelling (Roberts, 2005), while others argue that it is the Agulhas Current that maintains and forces this sub-surface structure 
(Chang, 2009; Boyd and Shillington, 1994). Our combined in-situ and satellite observations of ocean currents along the eastern margin of the Agulhas Bank show that Natal Pulses play a major role in setting up the isotherms on the Agulhas Bank. Interactions between the Agulhas Current and the shelf waters impact the thermocline structure of the Agulhas Bank through various processes. During Natal Pulse events, the strong cyclonic circulation within the core of the Natal Pulse meanders acts to draw nutrient-rich water upwards, affecting predominantly regions located above the mean position of the Agulhas Current's dynamical core. The strong upwelling associated with the cyclonic circulation set-up within Natal Pulses has previously been observed and documented (Bryden et al., 2005). Chapman and Largier (1989) suggested that the water drawn up in Natal Pulses may eventually move onto the Agulhas Bank, intensifying the seasonal thermocline from below. Our observations of the April 2009 Natal Pulse tend to confirm this hypothesis. The Natal Pulse of April 2009 was associated with an intense cell of cyclonic flow at its core (Figure 5a). As the April 2009 Natal Pulse reached its maximum offshore extent, a very steep decrease in water temperature was observed at the ADCP mooring site (Figure 5b and Figure 5d), suggesting that cold water upwelled within the core of the Natal Pulse was advected over the continental slope. The April 2009 Natal Pulse was also coincident with the coldest waters anomalies observed in the year-long in-situ record. The composite analysis conducted on the high resolution along-track altimetry data revealed that as the Natal Pulse meander grows, a smaller and weaker cell of cyclonic flow develops closer to the coast. The development of a secondary cell of diverging flow closer to the shore could be an important mechanism in 
the development of the cool ridge. Natal Pulses also influence the circulation and hydrography of the Agulhas Bank by driving strong intrusions of Agulhas Current water onto the shelf (Goschen and Schumann, 1990; Goschen, 1994). Such intrusions of Agulhas Current water onto the bank drive warm water inshore, further contributing the tilting of the isotherms closer inshore. The strong westerly currents observed when the leading edge of Natal Pulses intrudes over the Agulhas Bank could also promote Ekman veering in the bottom layers and further contribute to the shoaling of the thermocline between the Agulhas Current's front and the coast.

The availability of in-situ observations was useful to identify the shortcomings of the altimetry datasets. Comparisons between the in-situ current velocities and those derived from altimetry showed that geostrophic current velocities derived from the along-track altimetry were in good agreement with those measured in the upper layer of the water column on the shelf at the ADCP mooring site. But the AVISO mapped altimetry did not adequately capture the surface circulation at the ADCP mooring site. In a highly variable oceanic region such as on the shelf of the Agulhas Bank, sub-sampling combined to spatial smoothing and averaging can lead to the erroneous portrayal of the current velocity fields. In the AVISO mapped product, the temporal and spatial interpolation used to produced merged maps of geostrophic currents lead to the inadequate representation of both the synoptic and the time-averaged circulation over the shallower shelf regions of the Agulhas Bank. In-situ observations showed that current speeds for waters located along the Agulhas Bank shelf were significantly under-estimated in the AVISO mapped product (Section 3.3). The AVISO mapped product 
also erroneously portrayed the mean flow characteristics along the shelf of the mid-Agulhas Bank, indicating a mean flow towards the west, when in-situ measurements show a mean flow in the opposite direction: toward the east. The AVISO mapped altimetry product was also unable to adequately capture strong north-easterly flow reversals which occur when Natal Pulse reach their maximum offshore extent. In-situ current measurements revealed that at a sub-annual time-scale, most of variability observed at mooring site, on the shelf of the Agulhas Bank and east of $20^{\circ} \mathrm{E}$, occurred over time-scales of a week or less. Currently, observations combining several altimeters are able to observe mesoscale features of the ocean circulation at a sampling period of about 10 days (Le Traon and Dibarboure, 2002) and thus can not capture most of the variability observed in the ADCP current record. Sub-sampling in the along-track altimetry lead to an under-estimation of the current velocity during the Agulhas Current intrusions of April 2009 and December 2009. The along-track altimetry, although still suffering from a poor temporal resolution, was able to improve our understanding of the influence of Natal Pulses both in the outer shelf region and over the continental slope of the eastern and central Agulhas Bank.

\section{Conclusion}

Combined satellite and in-situ observations of ocean currents provided new insight on the influence of the Agulhas Current on the eastern and central Agulhas Bank. Our observations show that the strongest flow and temperature anomalies over the shelf regions of the Agulhas Bank and east of $20^{\circ} \mathrm{E}$ are due to large meanders in the Agulhas Current, or Natal Pulses. 
These Natal Pulses progress at an average speed of $10 \mathrm{~km} /$ day along the continental slope of the Agulhas Bank and tend to grow in size downstream. In the southern Agulhas region, Natal Pulses occur on average 1.7 times per year and have typical residence times of 65 days which imply that on average, the circulation on the eastern margin of the Agulhas Bank is influenced by Natal Pulses for about 110 days per year. As they progress southwards along the Agulhas Bank, Natal Pulses tend to get trapped along the shelf between $23^{\circ} \mathrm{E}$ and $26^{\circ} \mathrm{E}$. Natal Pulses drive a cyclonic flow anomaly which takes the shape of an ellipsoid, centred above the $3000 \mathrm{~m}$ isobath and extending up to $350 \mathrm{~km}$ along the shelf and $180 \mathrm{~km}$ in the direction perpendicular to the shelf. The cyclonic flow anomaly associated with Natal Pulses is asymmetric, with the north-eastward flow anomaly above the $1000 \mathrm{~m}$ isobath typically twice the magnitude of the south-westerly flow anomaly west of the $3000 \mathrm{~m}$ isobath. Over the shelf break, Agulhas Current intrusions associated with the leading edge of Natal Pulses drive a strong flow towards the west which favours the transport of particles and juvenile fish towards the Benguela upwelling ecosystem. Previous measurements have shown that Natal Pulses contributed to upwelling on the shelf slope and in the near-shore regions (Bryden et al., 2005). Our observations on the continental shelf of the central Agulhas Bank (Section 3.2) showed marked temperature decreases occurring in the upper and lower layers of the water column and associated with the passage of Natal Pulses (particularly during the event of April 2009). These results suggest that Natal Pulses promote the uplift of the isotherms both in the outer and inner shelf regions and may be instrumental in maintaining the cool ridge which is so important to the biology of the Agulhas Bank. 
While altimetry can be used successfully to improve our knowledge of Natal Pulses, it is inadequate to monitor the higher frequency variability observed in the shelf regions of the Agulhas Bank and east of $20^{\circ} \mathrm{E}$. Further studies using high-frequency satellite acquisitions or in-situ observations will be needed to better understand the full impact of the Agulhas Current on the oceanography of the Agulhas Bank.

\section{Acknowledgement}

Financial support for this study was provided by the CSIR Ecosystem Earth Observation group (PG project EEEO023). The first author would like to acknowledge the CSIR coastal systems group for the collection and processing of the in-situ datasets. Thanks also to PetroSA for giving us the permission to use the in-situ observations. The altimeter products were produced by Ssalto/Duacs and distributed by AVISO with support from CNES. Many thanks to the CERSAT and in particular to Jean-Francois Piollé for providing access to subsets of the SEVIRI SST data. 


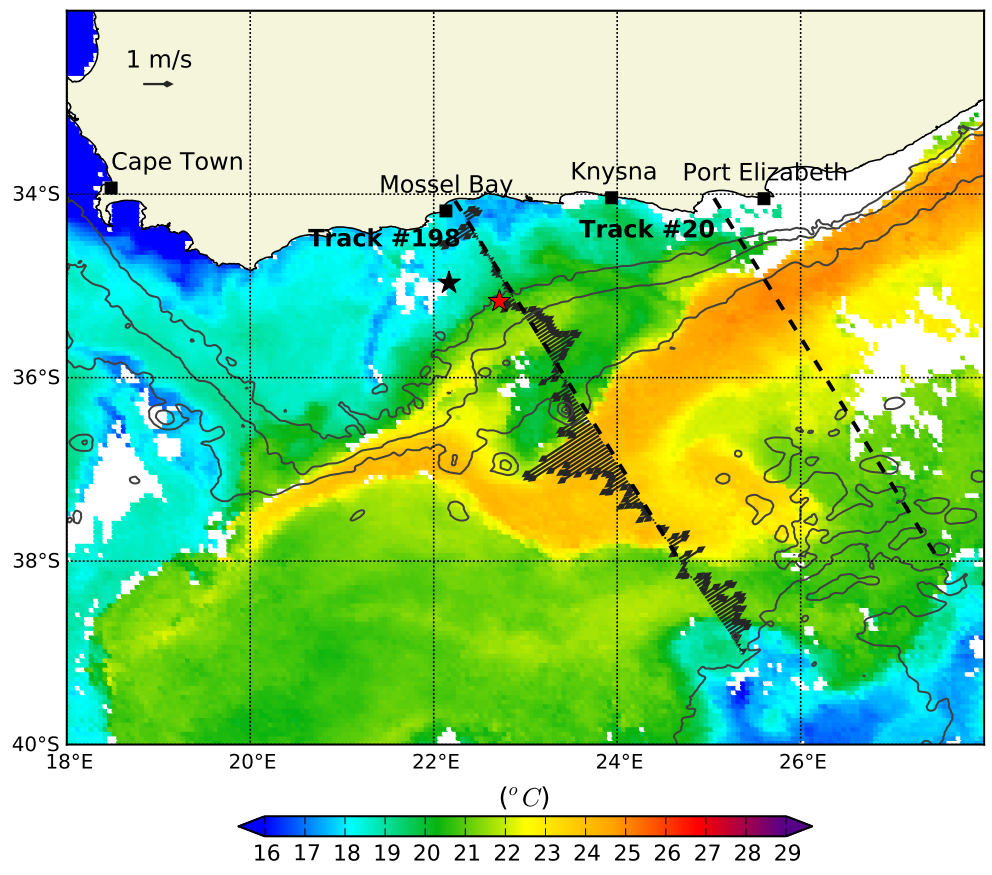

Figure 1: Daily composite of SEVIRI SST on 13 May 2009, during the passage of a Natal Pulse. Overlaid vectors represent the cross-track absolute geostrophic current velocities derived from the high resolution along-track altimetry. The black star shows the location of the wind anemometer. The red star shows the location of the ADCP mooring. The stippled black lines show the Topex/Jason altimetry Tracks \#020 and \#198. Thin black lines indicate the $200 \mathrm{~m}, 1000 \mathrm{~m}$ and $3000 \mathrm{~m}$ depth contours. 


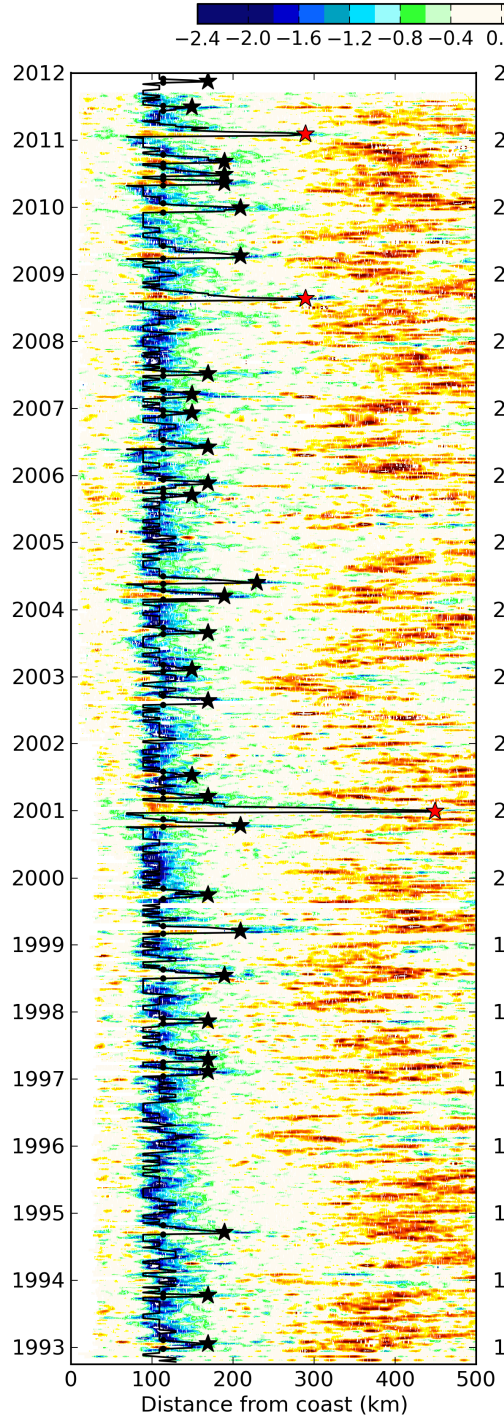

(a)

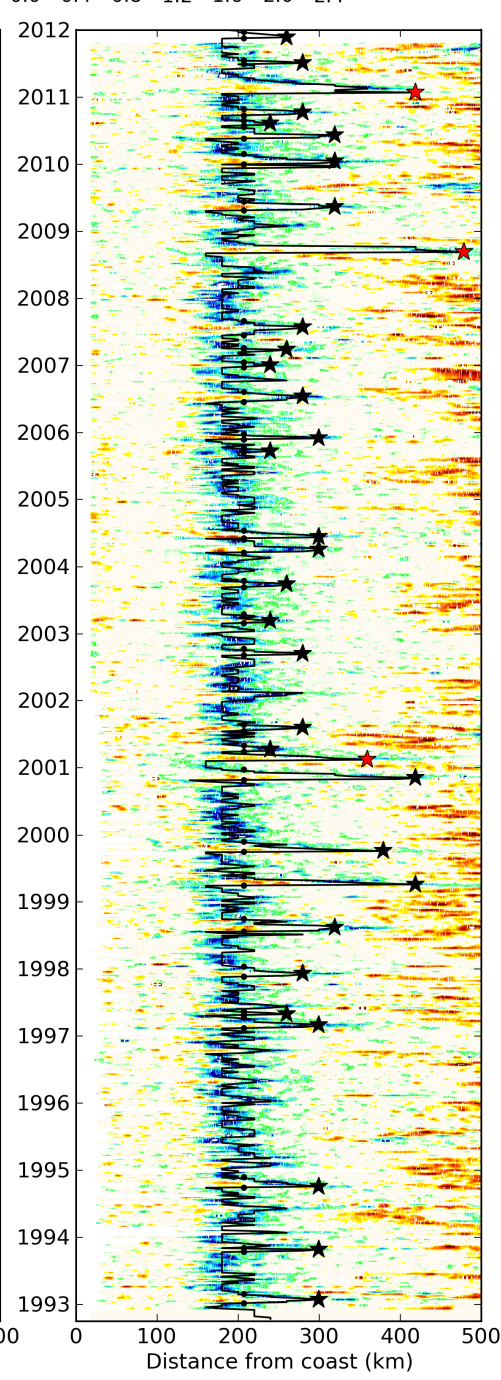

(b)

Figure 2: Hovmöller diagram of the cross-track velocities (in $m s^{-1}$ ) derived from the high resolution along-track altimetry at Tracks \#020 (a) and \#198 (b). Positive values (in shades of yellow and red) indicate a flow towards the North-East while negative values (in shades of green and blue) show a flow towards the South-West. The black line shows the position of the Agulhas Current core derived from the AVISO mapped product. Black stars in (a) indicate deviations in the path ${ }_{35}$ of the Agulhas Current along Track \#020 which exceed 1 standard deviation from the mean. Red stars in (a) show deviations in the Agulhas Current's path exceeding 3 standard deviations from the mean along Track \#020. In panel (b), stars show the same deviations in the Agulhas Current detected along Track \#020 once they reach Track \#198. 


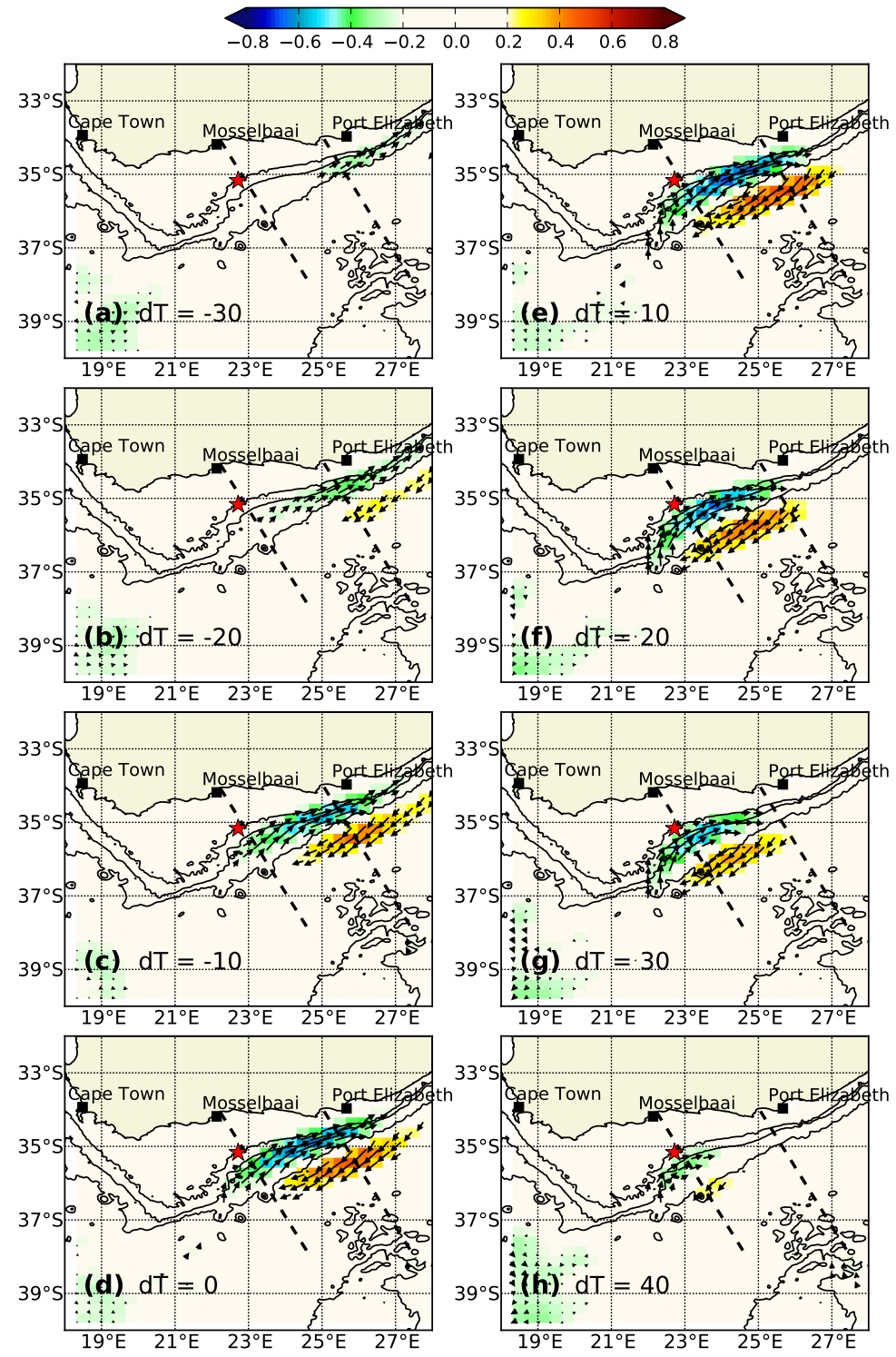

Figure 3: Composite maps of the AVISO absolute geostrophic velocity anomalies (in $m s^{-1}$ ) associated with the passage of Natal Pulses. Overlaid vectors show the magnitude and direction of the geostrophic anomalies for current speeds greater than $0.2 \mathrm{~ms}^{-1}$. The anomalies are computed with time lags dT varying from 30 days before the passage of the Natal Pulse at Track \#020 (a) to 40 days after the passage of the Natal Pulse at Track \#020 (h). The red star shows the location of the ADCP mooring, near the altimetry Track \#198. The $200 \mathrm{~m}, 1000 \mathrm{~m}$ and $3000 \mathrm{~m}$ isobaths are plotted as solid black lines. Stippled black lines show the location of altimetry Tracks \#020 and \#198. 

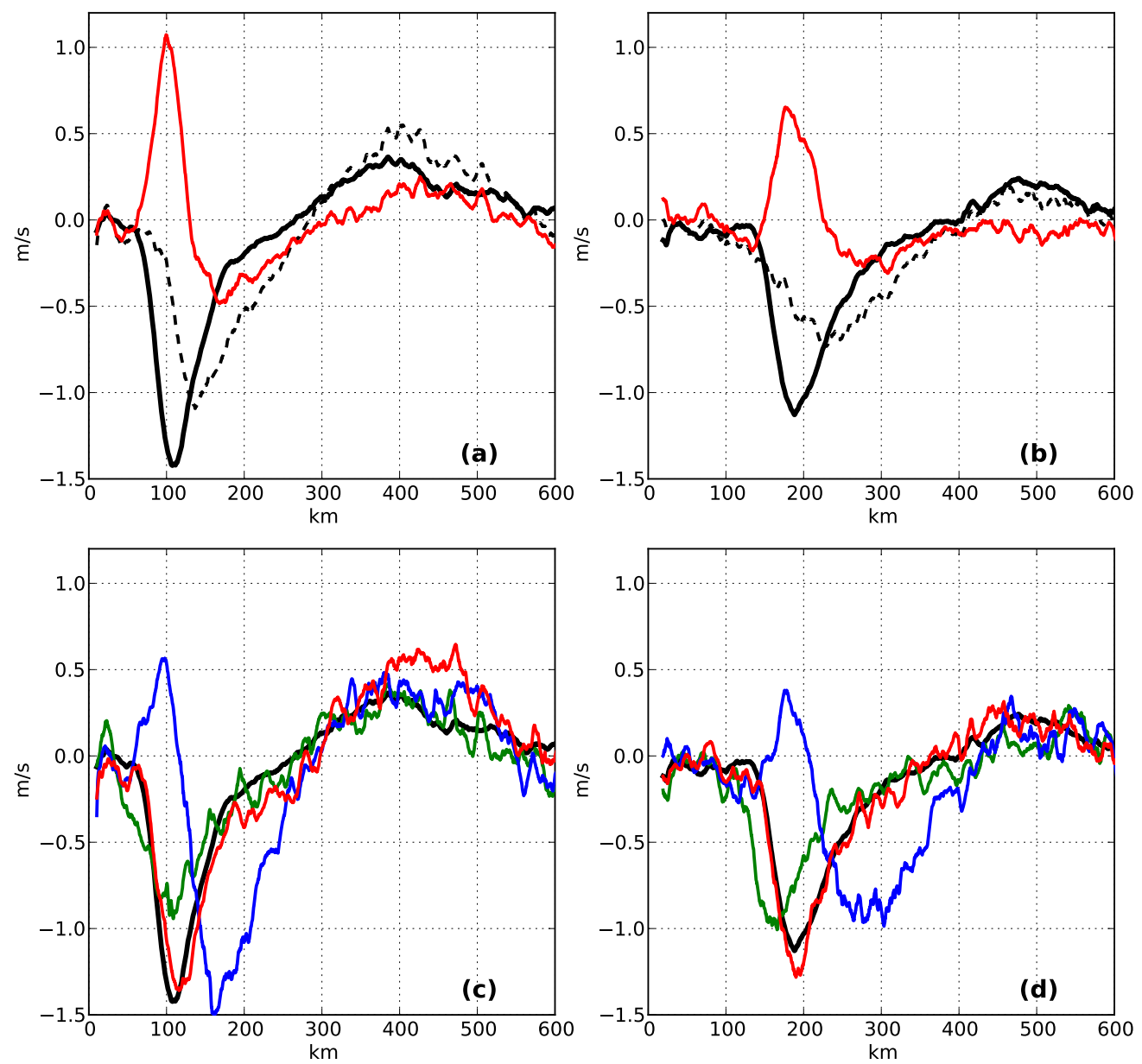

Figure 4: Composites of cross-track velocities derived from the high resolution along-track altimetry for Tracks \#020 (left) and \#198 (right). Solid black lines in all panels represent time-averaged cross-track velocities during conditions of no Natal Pulse. In (a) and (b), the black stippled lines show the averaged composite velocities during Natal Pulses and the red lines show the time-averaged cross-track velocity anomalies. In (c) and (d), composites of the cross-track velocities at the beginning, the peak and the end of Natal Pulses are plotted in green, blue and red, respectively 


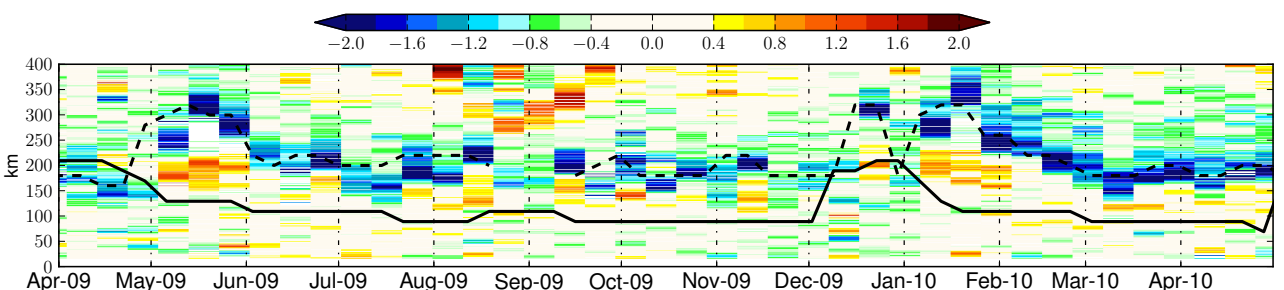

(a)

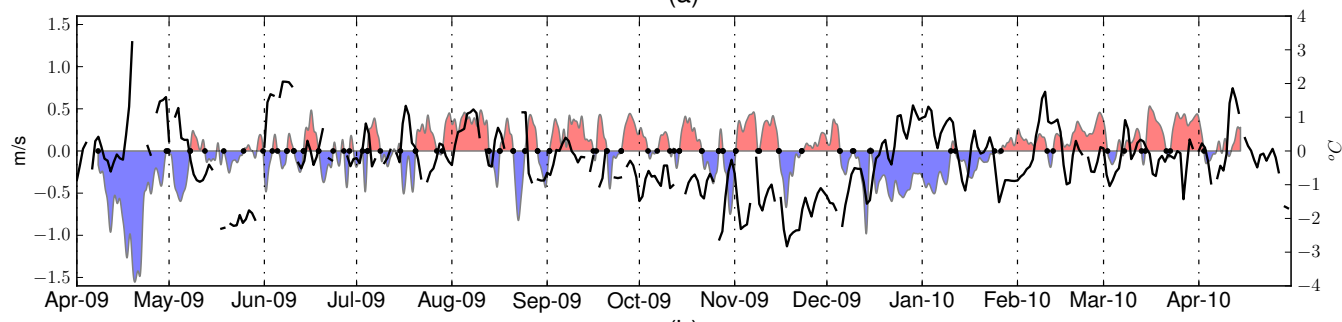

(b)

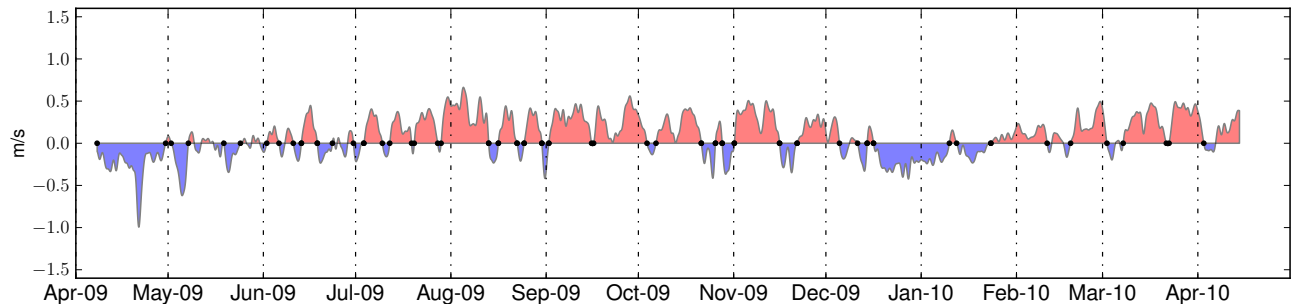

(c)

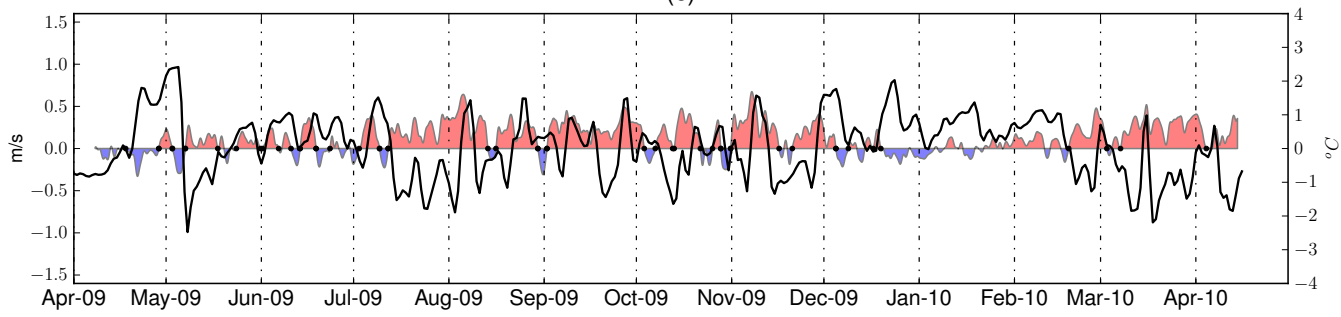

(d)

Figure 5: (a) Colour plot of the cross-track velocities (in $m s^{-1}$ ) derived from the alongtrack altimetry at Track \#198. Shades of blue show a south-westerly flow. Black lines in (a) represent the distance between the core of the Agulhas Current and the coast derived from the AVISO mapped dataset along Track \#020 (solid line) and Track \#198 (stippled line). Panels (b), (c) and (d) show variations in the ADCP measured easterly current at depth of $30 \mathrm{~m}, 130 \mathrm{~m}$ and $240 \mathrm{~m}$, respectively. Blue shadings highlight periods of westerly flow and red shadings indicate a flow towards the east. The black line in (b) shows SST anomalies derived from the SEVIRI dataset. In (d), the black line represents in-situ temperature anomalies at a depth o $3840 \mathrm{~m}$. 


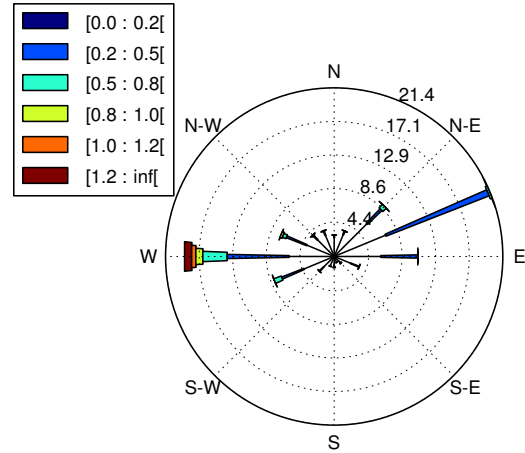

(a)

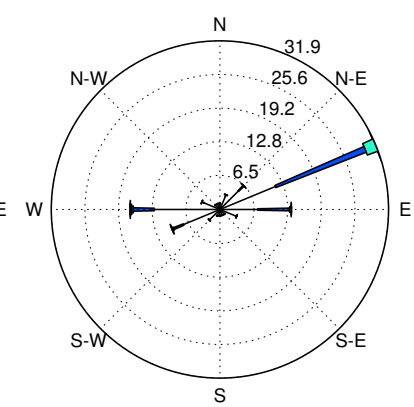

(b)

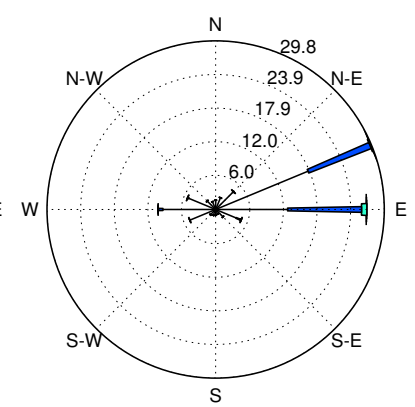

(c)

Figure 6: Current roses derived from the ADCP observations for the upper (a), intermediate (b) and lower (c) levels of the water column. Colour bands indicate current speed ranges in $m s^{-1}$. Values around the concentric circles show the percentage of time ocean currents are flowing towards a particular direction, with the longest spoke showing the current direction with the greatest frequency.

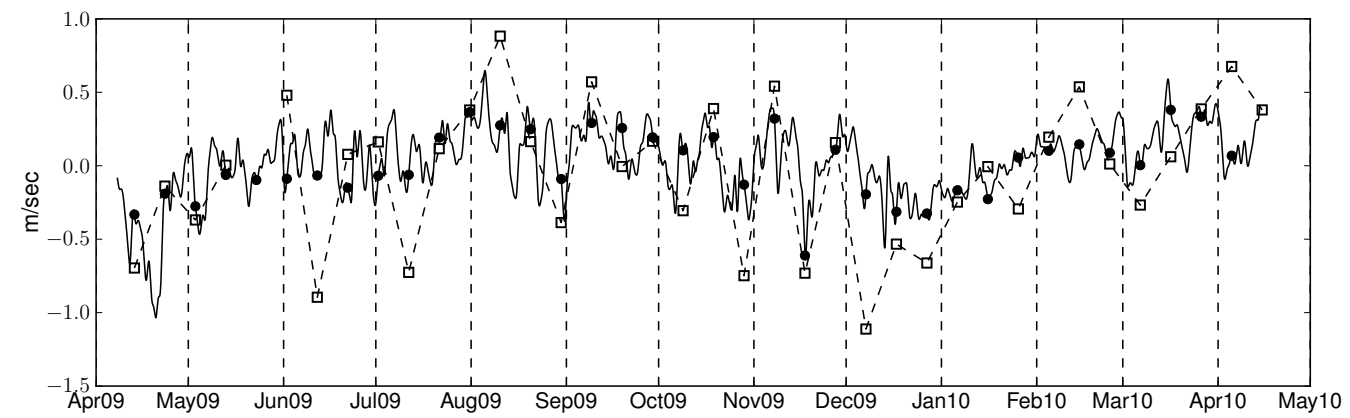

Figure 7: Comparisons between the high resolution along-track altimetry and the ADCP projected velocities at a depth of $30 \mathrm{~m}$. The along-track altimetry dataset is plotted with a stippled black line and square markers. The ADCP velocities are plotted in a solid black line, with round markers indicating ADCP observations closest in time to the altimeter's data acquisition. Positive values are indicative of a flow towards the north-east. 

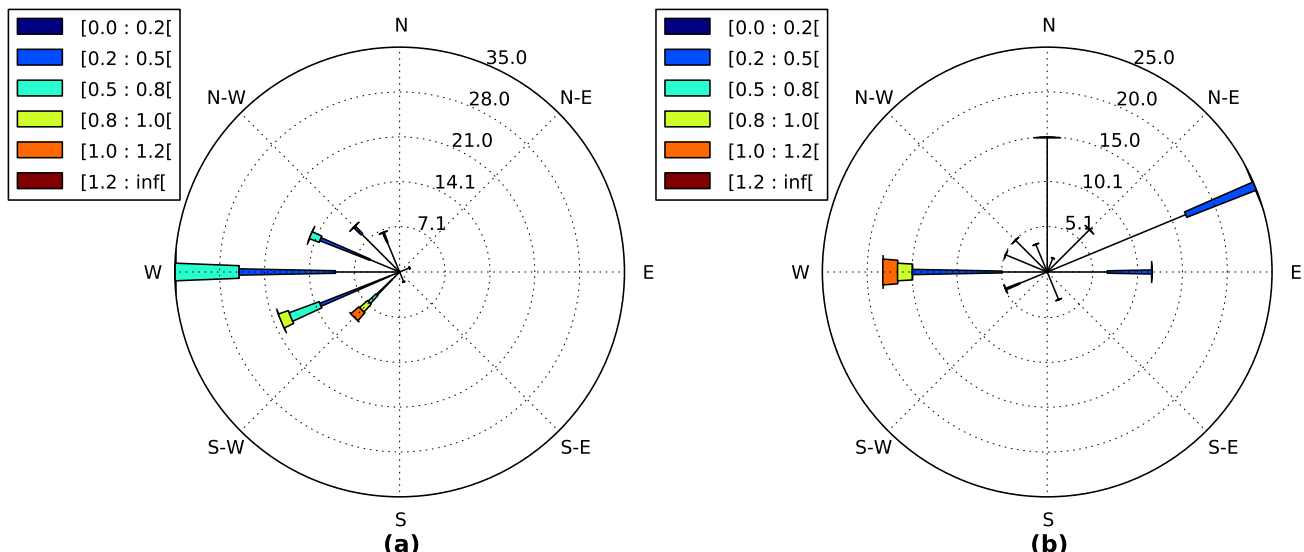

Figure 8: Current roses at the ADCP mooring location derived from the weekly AVISO mapped altimetry (a) and from weekly averages of ADCP observations at a $30 \mathrm{~m}$ depth (b). 


\section{References}

Beal, L.M., Bryden, H.L., 1999. The velocity and vorticity structure of the Agulhas Current at 32S. Journal of Geophysical Research: Oceans 104(C3), 5151-5176.

Blanke, B., Penven, P., Roy, C., Chang, N., Kokoszka, F., 2009. Ocean variability over the Agulhas Bank and its dynamical connection with the southern Benguela upwelling system. Journal of Geophysical Research: Oceans 114(C12), 19782012.

Boyd, A.J., Shillington, F.A., 1994. Physical forcing and circulation patterns on the Agulhas Bank. South African Journal of Science 90, 114-114.

Bryden, H.L., Beal, L.M., Duncan, L.M., 2005. Structure and transport of the Agulhas Current and its temporal variability. Journal of Oceanography 61, 479-492.

Chang, N., 2009. Numerical ocean model study of the Agulhas Bank and the Cool Ridge. Ph.D. thesis. University of Cape Town, Cape Town, South Africa,.

Chapman, P., Largier, J.L., 1989. On the origin of Agulhas Bank bottom water. South African Journal of Science 85, 515-519.

Goschen, W. S., .S.E.H., 1994. An Agulhas Current intrusion into Algoa Bay during August 1988. South African Journal of Marine Science 14(1), $47-57$. 
Goschen, W.S., Schumann, E.H., 1990. Agulhas Current variability and inshore structures off the Cape Province, South Africa. Journal of Geophysical Research: Oceans 95, 667-678.

Grundlingh, M., Mabille, E., Bergman, S., Watt, L., van Ballegooyen, R., Rossouw, M., 2010. Agulhas Bank metocean data current monitoring at the F-O and F-S Fields, December 2008 to April 2010. Summary report.

Hutchings, L., 1994. The Agulhas Bank: a synthesis of available information and a brief comparison with other east-coast shelf regions. South African Journal of Science 90(3), 179-185.

Hutchings, L., Beckley, L.E., Griffiths, M.H., Roberts, M.J., Sundby, S., van der Lingen C., 2002. Spawning on the edge: spawning grounds and nursery areas around the southern African coastline. Marine Freshwater Research 53, 307-318.

Hutchings, L., van der Lingen, C.D., Shannon, L.J., Crawford, R.J.M., Verheye, H.M.S., Bartholomae, C.H., Monteiro, P.M.S., 2009. The Benguela Current: an ecosystem of four components. Progress in Oceanography $83(1), 15-32$.

Jackson, J.M., Rainville, L., Roberts, M.J., McQuaid, C.D., Lutjeharms, J.R.E., 2012. Mesoscale bio-physical interactions between the Agulhas Current and the Agulhas Bank, South Africa. Continental Shelf Research 49, 10-24.

Krug, M., Tournadre, J., 2012. Satellite observations of an annual cycle in the Agulhas Current. Geophysical Research Letters 39(15). 
Le Traon, P.Y., Dibarboure, G., 2002. Velocity Mapping Capabilities of Present and Future Altimeter Missions: The Role of High-Frequency Signals. Journal of Atmospheric and Oceanic Technology 19, 2077-2087.

Leber, G., Beal, L.M., 2014. Evidence that the Agulhas Current transport is maintained during a meander. in Review .

Lee, J.S., 1981. Refined Filtering of image noise using local statistics. Computer graphics and image processing 15, 380-389. doi:10.1016/S0146$664 \mathrm{X}(81) 80018-4$.

Lutjeharms, J., Catzel, R., Valentine, H.R., 1989. Eddies and other boundary phenomena of the Agulhas Current. Continental Shelf Research 9, 597 616. doi:10.1016/0278-4343(89)90032-0.

Lutjeharms, J., Penven, P., Roy, C., 2003a. Modelling the shear edge eddies of the southern Agulhas Current. Continental Shelf Research 23, 10991115.

Lutjeharms, J.R.E., 2006. The Agulhas Current. Springer.

Lutjeharms, J.R.E., van Ballegooyen, R.C., 1984. Topographic control in the Agulhas Current system. Deep Sea Research Part A. Oceanographic Research Papers 31(11), 1321-1337.

Lutjeharms, J.R.E., Boebel, O., Rossby, H.T., 2003b. Agulhas cyclones. Deep-Sea Research II 50, 13 - 34. doi:10.1016/S0967-0645(02)00378-8. inter-ocean exchange around southern Africa.

Lutjeharms, J.R.E., Boebel, O., van der Vaart, P.C.F., de Ruijter, W.P.M., Rossby, T., Bryden, H.L., 2001. Evidence that the Natal Pulse involves the 
Agulhas Current to its full depth. Geophysical Research Letters 28(18), $3449-3452$.

Penven, P., Lutjeharms, J.R.E., Marchesiello, P., Roy, C., Weeks, S.J., 2001. Generation of cyclonic eddies by the Agulhas Current in the lee of the Agulhas Bank. Geophysical Research Letters 27, 1055-1058.

Probyn, T.A., Mitchellinnes, B.A., Brown, P.C., Hutchings, L., Carter, R.A., 1994. A review of primary production and related processes on the Agulhas Bank. South African Journal of Science 90, 166-173.

Rio, M.H., Guinehut, S., Larnicol, G., 2011. New CNES-CLS09 global mean dynamic topography computed from the combination of GRACE data, altimetry, and in situ measurements. Journal of Geophysical Research: Oceans 116, C07018. doi:10.1029/2010JC006505.

Roberts, M.J., 2005. Chokka squid (Loligo vulgaris reynaudii) abundance linked to changes in South Africas Agulhas Bank ecosystem during spawning and the early life cycle. Ices Journal of Marine Science 62, 3355.

Rouault, M.J., Mouche, A., Collard, F., Johannessen, J.A., Chapron, B., 2010. Mapping the Agulhas Current from space: an assessment of ASAR surface current velocities. Journal of Geophysical Research: Oceans 115, C10026. doi:10.1029/2009JC006050.

Rouault, M.J., Penven, P., 2011. New perspectives on Natal Pulses from satellite observations. Journal of Geophysical Research: Oceans 116(C7), C07013. 
Roy, C., van der Lingen, C.D., Coetzee, J.C., Lutjeharms, J.R.E., 2007. Abrupt environmental shift associated with changes in the distribution of Cape Anchovy Engraulis encrasicolus spawners in the southern Benguela. African Journal of Marine Science 29(3), 309-319.

Swart, V.P., Largier, J.L., 1987. Thermal structure of Agulhas Bank water. South African Journal of Science 5(1), 243-252.

Tournadre, J., Rouault, M.J., 2012. Geostrophic current speed: from gridded products to high resolution along-track, in: ESA GlobCurrent User Consultation Meeting.

Van der Vaart, P., de Ruijter, W., 2001. Stability of western boundary currents with an application to pulselike behavior of the Agulhas Current. Journal of Physical Oceanography 31, 2625-2644. 